\title{
PEMIKIRAN PENDIDIKAN FAZLUR RAHMAN
}

\section{Mustafa}

\begin{abstract}
ABSTRAK
Kelahiran seorang tokoh seperti Fazlur Rahman merupakan produk sejarah dari hasil integrasi pendidikan, kebudayaan dan sosial masyarakt yang mengitarinya. Dimulai dari keluarga yang disiplin dalam mendidik telah melahirkan generasi yang jujur dan pemberani. Sejak uur 10 tahun Fazlur Rahman telah hafal Al-qur'an dengan baik. Dan ia juga mampu berbahasa arab klasik, Persia, ingris, prancis, dan jerman disamping bahsa Latin dan Yunani. Sebagai pemikir islam yang terkemuka dan kredibe, dengan keberanian intelektual yang mencengangkan, bukan saja ia takut kepada kontroversi, bahkan ia melihat konttoversi adlah bagian dari pada kontroversi kreatifitas intelektual yang tak mungkin dihindari. Karya-karya yang dianggap saripati pengetahuannya dibidang kalam, Al-qur'an, tasauf, fikih, filsafat, wawasan kesejarahan dan pendidikan Islam, yang sejalan dengan matakuliah yang diberikan di beberapa perguuran tinggi di Amerika dan Eropa dan ia juga telah melakukan banyak kajian terhadap pemikiran Ibnu sina, Al-Gazali, Ibnu Taimiyah, Syaikh Waliyullah, Muhammad Ikbal. Khususnya pemikiran Rahman dalam pendidikan merupakan konstribusinya terutama terhadap modernisasi pendidikan islam, ayng di latarbelakangi oleh pengamatannya terhadap pemikiran pendidikan islam di era modern terutama di Timur Tengah, dimana tujuan pendidikan tidak searah dengan tujuan positif, rendahnya kuaitas anak didik dengan munculnya pribadi yang terpecah yang belum memiliki komitmen spiritual dan intelektual yang mendalam terhadap islam, dikotomi sistem pendidikan, sulitnya menemukan pendidik yang berkualitas dan profesional yang memilik pikiran ayng kreatif dan terpadu dan minimnya saran pendidikan seperti buku-buku yang tersedia di perpustakaan merupakan sorotan pemikiran Fazlir Rahman.
\end{abstract}

Kata kunci: Fazlur Rahman-Pemikiran-Pendidikan 


\section{A. PENDAhuluan}

Fazlur Rahman di lahirkan didaerah Hazarah (di daerah India Ingris) yang sekarang masuk wilayah Pakistan, 21 September 1919. ${ }^{1}$ Ayahnya maulana Sahab alDinadlah seorang alim terkenal lulusan Douband. Ayahnya meemrhatikan Rahman dlam mengaji dan menghafal al-Qur'an, sehingga pada usia 10 tahun, Rahman telah menghafal al-qur'an selruhnya. ${ }^{2}$ Pendidikan dalam keluarganyabenar-benar efektif dalam membentuk watak dan kepribadiannya untuk dpatmenghadapi kehidupan nyata. Menurut Rahman, ada ebebrapa faktor yang memengaruhi karakter dan kedalaman keagamaannya. Diantara faktor-faktor tersebut yang terpenting adalah ketekunan ayahnya yang mengajarkannya agama kepadanya di rumah dengan disiplin tinggi sehingga dia mampu menghadapi berbagai macam peradaban dan tantangan dialam modern, di samping pengajaran dari ibunya, terutama tentang kejujuran, kasih sayang serta ketulusan dari hatinya.

Hal lain yang memengaruhi pemikiran keagamaan Rahman adalh bahwa ia didik dlam keluarga dengan tradisi mazhab Hanafi yang banyak menggunkan rasio (ra'yu) disbanding mahab sunni lainnya. Setelah itu, di india ketika itu telah berkembang pemikiran yang agak liberal seperti yang dikembangkan oleh syaikh Waliyullah, Said Ahmad Khan, Sir Sayid, Amir Ali, dan Muhammad Iqbal.

Selanjutnya pada tahun 1993 Rahman melanjutkan studinya ke Lahore dan Mamasuki sekolah modern. Pada tahun 1940 dia menyelesaikan BA dalam bidang bahasa Arab di Universitas Punjab. Kemudian dua tahun berikutnya (1945) ia berhasil menyelesaikan Master dalam bidang yang sama di Universitas yang sama pula.

Empat tahun kemudian, pada tahun 1946, Rahman melanjudkan studinya di Universitas Oxford, Ingria. Dibawah bimbingan Profesor S. Van den Bergh dan H.A.R. Gibb, Rahman menyelesaikan program Ph.D pada tahun 1949, dengan

\footnotetext{
${ }^{1}$ Lihat Acikgence Alparslan, ' The Islamic Revival and Revorm: Fazlur Rahman's Life and Thought (1919-1988) ' dalam jurnal of Islamic research, vol. 4, 1990.h.287

${ }^{2}$ Liaht Fazlir Rahman, An Autobiographical Note, dlam journal of Islamic Research, Vol. 4, 1990, h. 287
} 
disertasi tentang Ibnu Sina. Dua tahun selang sisertasi tersebut di terbitkan oleh oxford University Press dengan judul Avicennas Pshicology . pada tahun 1959 karya suntungan Rahman dari kitab Al-Nafs karya Ibnu Sina diterbitkan oleh penerbit yang sama dengan judul Avicennas De Anima .

Saat kuliah di Universitas Oxford, lembaga pendidika yang telah maju di Barat, Rahman beroleh kesempatan mempelajari bahasa-bahasa Barat, sehingga ia menguasai bahasa Latin, Yunani, Ingris, Jerman, Turki, Arab, dan Urdu. Penguasa bahasa yang bagus sangat membantunya dalam memperdalam dan memperluas ilmu, terutama dlam studi-studi Islam melalui penelusuran literature-literatur keislaman yang di tulis para orientalis dlam bahasa mereka. Dengan pengalaman ini ia tak bersifat apologetic, tetapi justru lebih memperlihatkan penalaran objektif.

Setelah tuntas kuliah di oxford University, Rahman tak langsung pulang kenegerinya, Pakistan. Rahman mengajar beberapa tahun di Durhan University, dan berhasil menyelesaikan karya orisinal berjudul Prophecy in Islam: Philosophy orthodoxy.

Pada tahun 1960-an Rahman pulang ke Pakistan, dan dua tahun kemudian dia ditunjuk selaku direktur lembaga riset islam setelah sebelumnya menjabat sebagai staf di lembaga tersebut selama beberapa saat. Selama kepemimpinannya lembaga ini berhasil menebitkan dua jurnal ilmiah, Islamic Studies dan firk u-Nazar (berbahasa Urdu).Ketika mengelola lembaga riset ini, ia bekerja dngan sungguh-sungguh untuk mendapatkannya.

Selain itu, pada tahun 1964, Rahman di tunjuk sebagai anggota Dewan Penasihat Ideologi Islam Pemerintah Pakistan. Karena kedua tugas ini ia terdorong untuk menafsirkan kembali islam dalam istilah-istila yang rasional dan ilmiah gunah memenuhi kebutuhan masyarakat. Akan tetapi pada tahun 1969 ia melepas posisinya selaku anggota Dewan Penasehat Ideoogi Pemerintah Pakistan setelah beberapa saat sebelumnya ia melepas jabatan selaku direktur lembaga riset islam.

Sehabis melepas kedua jabatan di Pakistan, Rahman hijrah ke Barat. Ketika itu ia di terima sebagai tenaga pengajar di universitas California, Los Angel, Amerika. 
Kemudian pada tahun 1969, ia mulai menjabat Guru Besar kajian islam dalm berbagai aspeknya di Departement of Near Eastern Languages and Civilizatio, University Chicago. Ia menetap di Chicago kurang lebih 18 tahun, sampai meninggal dunia pada 26 juli $1988 .^{3}$

Selain memberi kuliah tentang al-qur'an, filsafat Islam, kajian-kajian tentang Imam Al-Gazali, Ibnu T/aimiyah, Syaikh Wliyullah, Muhammad Iqbal dan lain-lain, Rahman juga aktif sebagai pemimpin berbagai proyrk penelitian universitas tersebut. Salah satu proyek yang di pimpin bersama Prof.Dr. Leonard Bindert ialah tentang islam dan perubahan islam dan perubahan sosial yang melibatkan banyak sarjana yunior. Riset ini memusatkan perhatian pada lima masalah pokok, yaitu pendidikan agama dan perubahan peran ulama dan islam; syariah dan kemajuan ekonomi keluarga dalam masyarakat dan hukum Islam masa kini; Islam dan masalah Legalitas politik, serta perubahan konsep stratifikasi di dalam masyarakat Muslim masa kini. Riset ini di lakukan di Negara-negara Pakistan, Mesir, TUrki, Iran, Maroko, Dna Indonesia.

Berdasarkan paparan tersebut, dapat di ketahui bahwa Fazlur Rahman adalah pemikir islam terkemuka dan kredibel. Latar belakang keliarganya yang taat beragama, latar belakang pendidikannya yang kredibel, kemampuan intelektual dan keperbadian yang baik, ketekunannya dalam melakukan penelitian dan melaksanakan tigas-tugas, menyebabkan pemikiran dan gagasannya pantas untuk di jadikan rijikan.

\section{B. PEMIKIRAN PENDIDIKAN FAZLUR RAHMAN}

Fazlur Rahman berbicara tentang berbagai aspek Fundalmental tentang pendidikan, antara lain tentang dasar pemikiran pendidikan Islam, termasuk strategi pendidikan Islam sekarang menurut Fazlur Rahman cenderung bersifat defensive, yaitu hanya menyelamatkan pikiran kaum muslimin dari pencemaran dan kesusahan yang di timbulkan oleh dampak gagasan-gagasan barat yang dapat melalui berbagai

\footnotetext{
${ }^{3}$ Lihat Mumtaz Ahmad, "In memorian Profesor Fazlur Rahman"' dalam The American Journal af Islamic social science, Vol. 5, No. 1, 1988, h. 2.
} 
disiplin Ilmu, terutama gagasan-gagasan yang mengancam kerusakan standar-standar moralitas tradisional ${ }^{4}$ Islam dan lain-lain sebagai berikut:

\section{Dasar Pemikiran Pendidikan}

Pemikiran Fzlur Rahman baik dalam bidang pendidikan maupun lainnya di bangun atas dasar pemahamannya yang mendalam tentang khasanah intelektual Islam di zamnan klasik untuk di temukan spiritnya gunah menyelesaikan berbagai masalah kehidupan modern. Hal ini misalnya dapat di lihat dari analisis yang di berikannya terhadap pertumbuhan dan perkembangan pendidikan Islam yang di laksanakan mulai zaman Rasulullah Saw. Sampai pada zaman Abbasiyah. Ia misalnya mengatakan pendidikan Islam di zman klasik itu merupakan metode membaca dan menulis, tetapi yang paling lazim ialah menghapal al-qur' dan al-Hadits. Namun, ada juga kelompok kecil yang berusaha mengembangkan kemampuan intelektual. Kemudian pada masa Abbasiyah, khalifah-khalifah tertentu, seperti Harun ar-Rasyid dan Al-Ma'mum ,enekankan adu pendapat di antara para pelajar di istana mengenai persoalan Logoka, hikum, gramatika,dan sebagainya.

Melalui kajiannya terhadap berbagai literatur Klasik Fazlur Rahman memperkenalkan gagasan dan pemikirannya tentang pembaruan pendidikan. Bagi dia, pembaruan pendidikan Ilam dapat di lakuakan dengan menerima pendidikan sekuler modern, kemudian berusaha memasukinya dengan konsep-konsep Islam. Upayah pembaruan pendidikan Islam ini menurutnya dapat di tempuh dengan cara:

a. Membangkitkan Ideologi umat Islam tentang pentingnya belajar dan mengembangkan ilmu pengetahuan.

b. Berusaha mengikis dualism sistim pendidikan umat Islam. Pada satu sisi ada pendidikan tradisional (agama), dan pada sisi lain, ad pendidian modern (sekuler). Karena itu, perlu ad upayah mengintregrasikan antara keduanya.

\footnotetext{
${ }^{4}$ Lihat Fazlur Rahman, Islam and Modrnity, op. cit, h. 86, dalam subtrisno, Fazlur Rahman, Kajian terhadap Metode, epistemology dan Sistem Pendidikan, op. cip, h.172
} 
c. Menyadari betapa pentingnya bahasa dalam pendidikan dan sebagai alat untuk mengeluarkan pendapat-pendapat yang orisinil. Bahkan ia menegaskan bahwa umat Islam merupakan masyarakat tampa bahasa.

d. Pembaruan di bidang metode pendidikan Isalm, yaitu beralih dari metode berulang-ulang (membeo) dan menghapal pelajaran ke metode memahami dan menganalisis.

\section{Pengertian Pendidikan Islam}

Menurut Fazlur Rahman, pendidikan dpat mencakup dua pengertian besar :

a. Pendidikan dalam pengertian praktis, yaitu pendidikan yang di laksanakan di dunia Islam,seperti yang dilaksanakan di Pakistan,Mesir,sudan, Saudi, Iran, Turki, Maroko dan sebagainya,mulai dari pendidikan dasar hingga perguruan tinggi. Dalam konterks Indonesia, meliputi pendidikan di pesantren, madrasah (mulai dari tingkat ibtidaiyah sampai dengan aliyah), dan di perguruan tinggi islam bahkan dapat juga mencakup pendidikan agama islam di sekolah mulai dari tingkat dasar sampai hingga lanjut atas, serta pendidikan agama islam di perguruan tinggi umum.

b. Pendidikan islam dalam arti intelektualisme islam, seperti di selenggarakan di perguruan tinggi. Selain itu endidikan islam menurut Rahman, dapat juga di pahami sebagai proses untuk menghasilkan manusia integratif, yang padanya terkumpul sifat-sifat seperti kritis, kreatif, dinamis, inofativ, progresi, adil, jujur, dan sebagainya. Lulusan atau ilmuan yang dihasilkan pendidikan yang demikan itu di harapkan dapat memberikan alternative solusi atau problem-problem yang di alami manusia di muka bumi.

\section{Tujuan Pendidikan}

Menurut Fazlur Rahman, tujuan pendidikan ialah mengembangkan manusia sedemikian rupa, sehingga semua pengetahuan yang di perolehnya akan menjadi organ pada keseluruhan pribadi yang kreatif, yang memungkinkan manusia dapat memanfaatkan sumber-sumber alam untuk kebaikan umat manusia dan untuk 
menciptakan keadilan, kemauan dan keteraturan dunia. ${ }^{5}$ Menurut Rahman, tujuan pendidikan islam selama ini lebih cenderung berorientasi kepada kehidupan akhirat semata, dan bersifat defensif, hal ini sebagaimana di katakannya:

Strategi pendidikan islam yang ada selama ini tidaklah benar-benar di arahkan kepada tujuan yang positif, tetapi lebih cenderung bersifat defensif yaitu untuk menyelamatkan pikiran kaum muslim dari pencemaran atau kerusakan yang di timbulkan oleh dampak gagasan-gagasan barat yang datang melalui disiplin ilmu, terutama gagasan-gagasan yang akan meletakan standar moralitas islam. ${ }^{6}$

Dalam kondisi spiritual itu, strategi pendidikan islam yang dikembangkan di seluruh dunia islam secara universal bersifat mekanis. ${ }^{7}$ Akibatnya muncul golongan yang menolak segala apa yang berbau barat, bahkan ada pula yang mengharapkan pengambilan ilmu dan teknologinya. ${ }^{8}$ Maka tujuan pendidikan yang defensif itu harus dirubah pendidikan yang berorientasi dunia dan akhirat Menurutnya:

Tujuan pendidikan islam dalam Al-Quran adalah untuk mengembangkan kemampuan inti manusia dengan cara sedemikian rupa sehingga seluruh ilmu pengetahuan yang diperolehnya akan menyatu dengan kepribadian kreatifnya. ${ }^{9}$

Beban psikologi umat islam dalam menghadapi barat harus segera dihilangkan dengan cara melakukan kajian menyeluruh secara historis dan sistematis

\footnotetext{
${ }^{5}$ Lihat Fazlur Rahman, The Qur'anic Solucion of Pakistan's Edication Problem's, dalam Sutrisno, Kajian Terhadap Epistemologi dan Sistem Pendidikan, (Cet; 1.Yogyakarta : Pustaka Pelajar, 2006), h. 171.

${ }^{6}$ The Curren Strategy, as we Shaal presently, is sot so much aimed at a positive goal; it seems rather to be every devensife one; to save the minds of Muslim from being spoiled or even destroyed under the impact of wastres ideals coming thorugh various desciplines, particulary ideas that threaten to undermine the traditional standarts of islam ics morality. Fazlur Rahman, Islam dan Modeity Transformation of Intelectual Tradition (Chicago and London : The University of Chicago Press, 1984), h.46.

${ }^{7}$ Ibid

${ }^{8}$ A. Syafi'l Ma'arif, Peta Bumi Intelegtualisme Islam di Indonesia (Bandung : Mizan, 1993 ),h.145.

${ }^{9}$ Fazlur Rahman, 'The Qur'anic Soluction of Pakistan Educational Problems ' dalam “Islamic Studies, Vol.6 No.4 Tahun 1967, h. 315.
} 
mengenai perkembangan disiplin-disiplin ilmu, seperti teologi, hukum, etika, hadis ilmu-ilmu sosial, filsafat, dengan berpegang kepada Al-Quran sebagai penilai. Sebab disiplin ilmu-ilmu islam yang telah berkembang dalam sejarah itulah yang memberikan kontinuitas kepada wujud intelektual dan spiritual masyarakat Muslim. Sehingga upaya ini diharapkan dapat menghilangkan beban psikologi umat islam menghadapi Barat. ${ }^{10}$

Sikap negatif umat islam terhadap ilmu pengetahuan juga harus berubah. Sebab menurut Rahman, tak ada yang salah ilmu pengetahuan, yang salah ialah penggunanya. Dalam Al-Quran kata al-ilmu (ilmu pengetahuan) digunakan untuk semua jenis ilmu pengetahuan. Contoh, ketika Allah mengajarkan bagaimana daud membuat baju perang, itu juga al-ilmu. Bahkan sihir, sebagaimana yang dihajarkan harut dan marut kepada manusia, merupakan salah satu jenis al-ilmu meskipun jelek dalam arti praktek dan pemakaiannya. Sebab banyak yang menyalahgunakan sihir itu untuk memisahkan suami dan istri. Begitu pula hal-hal yang memberikan wawasan baru pada akal termasuk ilmu. Dengan demikian kajian islam secara menyeluruh secara historis dan sitematis, radikal tenteang perkembangan disiplin ilmu-ilmu keislaman, di samping dapat menghilangkan beban psikologi umat islam dalam menghadapi barat, juga dapat berfungsi untuk mengintegrasikan pemikiran islam, serta menimbang lebih lanjut nilai perkembangan historis itu untuk dapat merekontruksi ilmu-ilmu islam bagi mas depan.

Selain itu, pendidikan menurut Fazlur Rahman juga menekankan aspek moral, ia mengatakan, bahwa tanggung jawab pendidikan yang pertama adalah menanamkan pada pikira-pikiran siswa mereka dengan nilai-nilai moral . pendidikan islam didasarkan pada ideology islam. Oleh karena itu, pada hakikatnya pendidikan islam tidak dapat meninggalkan keterlibatannya pada persepsi benar dan salah. Dalam

\footnotetext{
${ }^{10}$ The purpose of education according to the Qur'an, is to develop the inner faculties of man in such a way that all the know gained by will become organic to his total creative personality. Ibid, Lihat juga Taufik Adnan Amal, Islam dan Tantangan Modernitas : Studi atas Pemikiran Hukum Faflur Rahman (Bandung : Mizan, 1993), h.133.
} 
hubungan ini Fazlur Rahman menunjukkan bahwa dalam Al-Quran sering dijumpai ayat-ayat membicarakan pasangan antara Al-dunya dan Al-hirah. Al-dun-ya bermakna bernilai lebih rendah, sisi kehidupan materil, sedikit hasil serta tidak memuaskan. Sementara al-akhirah menunjukan sisi sebaliknya, yakni bernilai lebih tinggi inilah yang menjadi tujuan, bukan yang lebih rendah. Selain itu, Al-Quran juga menyuruh mempelajari kejadian yang terjadi pada diri sendiri, alam semesta dan sejarah umat manusia dimuka bumi dengan cermat dan mendalam serta mengambil pelajaran darinya agar dapat menggunakan pengetahuannya dengan tepat, serta tidak mengikuti orang yang berbuat kerusakan, oleh karena itu, tujuan umat pendidikan adalah untuk menyelamatkan manusia mulai dari diri sendiri oleh diri sendiri. ${ }^{11}$

Selain itu, pendidikan seharusnya tidak hanya menekankan aspek kognitif, namun juga aspek efektif dan psikomotorik. Bahkan sifat ini memancar pada muridmuridnya, seperti syafi'I dan ma'arif dan Nurcholish Madjid. Sifat modernis dan kritis terlihat pada rumusan dan metode pembelajaran yang ia tawarkan. Pada tujuan pendidikan, ia menginginkan agar lulsan pendidikan terbina seluruh protensinya: konigtif,efektif,dan psikomotorik, menjadi manusia yang kreatif, inovatif, dinamis, progresif, adil dan jujur. Pada metode pembelajaran bukan ditekankan pada memberikan ilmu pada murid,ataau murid memperoleh usahanya sendiri.

\section{Problem Pendidikan Islam}

Menurut Fazlur Rahman, pendidikan Islam menghadapi berbagai problem, yaitu problem ideologis, dualism sisitem pendidikan, bahasa, dan problem metode pembelajaran.

Berkaitan dengan problem yang pertama(ideologis), Rahman menjelaskan bahwa orang-orang islam mempunyai problem ideologis. Mereka tidak dapat mengaitkan secara efektif pentingnya pengetahuan dengan orientasi ideologinya. Akibatnya

\footnotetext{
${ }^{11} \mathrm{Ibid}$, h. $136-137$
} 
masyarakat muslim tidak terdorong untuk belajar. Tampaknya mereka tidak mempunyai tujuan hidup. Secara umum, terdapat kegagalan dalam menghubungkan prestasi pendidikan umat islam dengan amanah ideology mereka. Masyarakat tidak sadar bahwamereka berada dibawah perintah moral kewajiban islam untuk menuntut ilmu pengetahuan.

Selanjutnya berkaitan dengan problem yang kedua yaitu (dualism sisitem pendidikan) Rahman menjelaskan sebagai berikut: "yang terkait erat dengan yang pertama adalah bencana umat islam dengan adanya dualisme, dikotomi dalam sistem pendidikan." Pada satu sisi disebut dengan sistem pendidian "Ulama" yang dilaksanakan di madrasah, begitu tertinggal sehingga sekarang hasilnya betul-betul mengecewakan. Produk dari sistem ini, bagi Rahman tak dapat hidup di dunia modern dan tidak bisa mengikuti perkembangan zaman. Kuriulum dan silabinya harus diubah secara radial dan mendasar agar dapat bersaing dalam kehidupan modern. Prinsip-prinsip dasar ilmu sosial, Wordview sains modern dan pengantar sejarah dunia bersama-sama dengan ilmu-ilmu humoniora modern harus dimasukan ke dalam silabi guna menambah disiplin-disiplin spesialis agama. Namun, penting juga dipahami tentang kenyataan bahwa sistem pendidikan modern masyarakat islam yang di laksanakan di universitas-universitas telah berkembang, namun sama sekali tanpa menyentuh ideology dan nilai sosial serta budaya islam. Mahasiswa tidak terinspirasi sama sekali dengan cita-cita yang mulia. Hasil strateginya ialah bahwa standar pendidikan islam memburuk dan dibawah pengaruh secara tiba-tiba dari perkembangan ekonomi, bahkan dasar minimal dari rasa jujur dan tanggung jawab tidak timbul. Dengan demikian, kedua sistem pendidikan (islam tradisionaldan barat sekuler) ini tersakiti oleh bentuk-bentuk fragmentasi yang paling jelek.

Pada bagian berikutnya, Fazlur Rahman menjelaskan akibat dari kondisi dualism tersebut diatas, yakni pencarian pengetahuan umat islam secara umum sia-sia pasif dan tidak kreatif. Sistem madrasah yang tidak asli dan tidak kreatif itu menjadi paten. Namun sayang sistem pendidikan modern di dunia islam pun begitu jua. Dewasa ini 
umat islam tengah berada pada abad pendidikan modern, namuncara belajar mereka belum mampu menambah nilai orisinalitas dan investasi pengetahuan kemanusiaan, terutama pada ilmu humoniora dan ilmu sosial, dan kualitas sarjana muslim benarbenar rendah. Jika umat islam tidak menghasilkan pemikir berkualitas bagus dalam humoniora dan ilmu-ilmu sosial, mereka tidak dapat berharap mampu memberikan kontribusi yang berharga sekalipun pada ilmu-ilmu murni. Kerena itu ilmu murni tidak dapat di tanamkan pada ruang kosong dan terpisah dari ilmu-ilmu yang lain.

Berkaitan dengan problem yang ketiga (bahasa), Rahman menjelaskan sebagai berikut: terkait dengan itu adalah problem lain yang sama pentingnya, yaitu problem bahasa. Problem bahasa selalu terkait dengan pendidikan tinggi dan pemikiran, kecuali dilahirkan dengan kata-kata (bahasa) jika tidak ada kata-kata (karena tak ada bahasa yang memadai), konsep-konsep yang bermutu tak akan muncul. Akibat peniruan dan pengulangan seperti halnya burung beo adalah bukan pemikiran rasional. Kontroversi bahasa yang sering di kemukakan, hendaknya dipisahkan dari emosionalisme politik, dan umat islam sekarang harus mengembangkan satu bahasa secara memadai dan cepat, karena mereka berpacu dengan waktu kemajuan dunia tidak akan berhenti manati mereka, dan tidak pula memilikialasan yang khusus untuk memaklumi ketertingalan mereka. ${ }^{12}$

Selanjutnya, Rhman mengakui bahwa selam ini ia mempunyai piiran yang berharga yang di tulis dalam bahasa inggris, akan tetapi seorang nasionalis, sampai sekarang ia masih menganggap bahasa inggris sebagai bahasa asing. Walaupun, mereka juga belum dapat mengembangkan bahasa urdu maupun bahasa Bengali, yang semestinya secara tulus mendesak kedua bahasa itu pantas di kembangkan. Kedua bahasa itu mempunyai sejarah dan sastra, dan tentu saja mempunyai kelebihan terkait erat dengan tradisi masa lalu mereka. Akan tetapi, isu bahasa itu syangnya menjadi subjek perdbatan emosional politis. Ketika mereka berdebat, pikiran mereka tentu

\footnotetext{
${ }^{12}$ Fazlur Rahman, The Qur'anic Soluction, op.cit. h. 322.
} 
saja membusuk. Padahal seharusnya mereka menjadi pemiir yang bermutu dan kreatif.

Adapun yang berkaitan dengan problem yang keempat (metode pembelajaran), Fazlur Rahman memberikan gambara pendidikan di lingkungan umat islam di era barat pertengahan dan pra modern sebagai berikut: kelemahan pokok yang dirasakan dalam proses pembelajaran di lingkungan masyarakat muslim pada abad pertengahan, juga pada masa pra modern, adalah konsep tentang pengetahuan (knowledge). Bertolak belakang dengan sikap dan cara berpikir keilmua ke era modern, mereka memandang bahwa pengetahuan sebagai sesuatu yang pada dasarnya harus di cari dan di temukan atau dibangun secara sistematis oleh akal pikiran manusia sendiri. Dengan mengandalkan peran akal manusia untuk memperoleh imu pengetahuan, siap pengetahuan di abad pertengahan menekankan kenyataan bahwa pengetahuan adalah sesuatu yang "diperoleh". Sikap dan posisi akan pikiran lebih bersikap pasif dan resptif dari pada bersifay kreatif dan positif. Didunia muslim, konsepsi dan mentalitas cara berpikir yang bertolak belakang ini menjadi lebih kuat lagi, lantaran ada bentuk ilmu pengetahuan yang ditransmisikan begitu saja atau juga sering disebut pengetahuan "tradisional" yang didasarkan pada penukilan dan pendengaran di satu pihak, daan konsep pengetahuan yang bersifat "rasional" dipihak lain. ${ }^{13}$

Selain itu Rahman juga menjelaskan, bahwa sekarang siswa-siswa yang tertarik pada pendidikan islam hanya mereka yang tidak diterima pada bidang-bidang dasar.

\section{Metode Pendidikan}

Konsep metode pemikiran pendidikan Fazlur Rahman yang berorientasi pada AlQuran, terkait dengan usaha pemecahan masalah di atas. Dari pencariannya itu ditemukan moral dan keadilan sosial. Dari sini kemudian ia temuka tiga kata kunci etika Al-Quran yaitu: iman,islam, dan takwa. Ketiga kata kunci tersebut mengandung

\footnotetext{
${ }^{13}$ Fazlur Rahman, Islam (Cet; 1: Jakarta: Bulan Bintang, 1987), h. 191.
} 
maksud yang sama yaitu percaya, menyerahkan diri, dengan mentaatisegala yang diperintah Allah swt dan meninggalkan segala yang dilarangnya. Pendidikan Islam pangkalnya adalah mengarahkan peserta didik untuk memiliki etika Al-Quran. Dengan kemampuan untuk mengatur segala yang ada di ala mini untuk kemaslahatan seluruh kehidupan umat manusia. Islam mengebangkan ilmu bertolak dari iman, islam dan takwa.

Ilmu dan teknologi dikembangkan untuk mamupuk keimanan, bukan untuk mengerosikannya. Metode berpikir harus tertata dengan baik, sinkron dan sekaligus konheren dengan keimanan kepada Allah, Rasul, Kitabullah,Malaikat,Hari Akhir dan takdir keimana bukan dipupuk secara dokmatis, melainkan di pupuk secara rasional. Bukan rasional pasivistik (yang hanya menyangkut keimanan empiric sensual), tetapi rasional entologis (yang mengakui kebenaran empiric sensual, Logoik, dan etik); yang aksiologos, yaitu mengakui nilai-nilai sensual, logic dan transcendental; dan yang epistemologis yang menggunakan pembuktian kebenaran yang bukan hanya menjangkau yang sosial dan logic saja, melainkan juga mengguankan metode berpikir yang mampu menjangkau etik, dan kebenaran transdental.

\section{KESIMPULAN}

Berdasarkan dan analisis sebagaimana tersebut di atas, dapat di kemukakan sebarapa catatan kesimpulan pemikiran Fazlur Rahman sebagai berikut:

1) Bahwa gagasan dan pemikiran Fazlur Rahman di dasarkan pada upaya mengatasi empat problem yang di hadapi umat, yaitu problem ediologos, problem dualism dalam sistem pemdidikan, problem bahasa, dan problem metode pembelajaran keempat macam problem ini secara sosiologis empiris berberdasarkan pada problem yang di hadapi Negara Pakistan pada waktu itu. Namun, karena keadaan Negara Pakistan tersebut memiliki kesamaan dngan problem yang di hadapi Negara-negara islam, maka gagasan dan pemikiran Fazlur Rahman dalm mengatur problem ytersebut juga dapat di jadikan bahan renungan oleh Negara- 
negara berkembang lainnya, separti Indonesia, empat macam problem juga di hadapi Indonesia dan Negara-negara Islam lainnya.

2) Selain konsep pendidikan di dasrkan pada masalah yang harus di pecahkan tersebut, konsep pendidikan Fazlur Rahman juga tampak di pengaruhi oleh sikap dan kepribadiannya sebagai orang modernis.Fazlur Rahman sebagai orang modernis sejati, dengan sendirinya sifat ini menyatu dalam dirinya. Sifat kritis yang semula berangkat dari kritis terhadap wariosan islam sendiri dan peradaban barat, kemudian berkembang ke selluruh aspek hidupnya,. Hingga pada akhirnya, sifat ini memancar pada pola pikir, perhatian, perkataan dan perbuatannya.

3) Pemikiran pendidikan Fazlur Rahman sangat terkait erat dengan upaya memecahkan masalah yang dihadapi umat. Melalui sikap-sikap yang tulus dan kreatif, inovatif, dinamis dan seterusnya lulusan pendidikan diharapkan dapat memecahkan masalah yang dihadapi masyarakat. Memecahkan masalah tidak hanya dalam konteks pengetahuan saja, tetapi dalam semua aspek kehidupan. Pemecahan masalah bergerak dari masalah yang sederhana yang akan menggunakan akal sehat sampai pada pemecahan masalah muskil yang menuntut prosedur berpikir yang lebih kompleks. Dengan demikian, fungsi pendidikan dari sisi sosial sangat strategis. Akan tetapi, fungsi ini tidak dapat berdiri sendiri, melainkan sangat bergantung pada sistem pengetahuannya. Oleh karna itu, tidak di ragukan lagi, bahwa cara yang terbaik untuk mendobrak stagnasi peradaban islam harus dimulai dari penyusunan konsep sistem pengetahuan yang dinamis, dan dengan cara demikian, pendidikan akan mengalami kemajuan, kalu pendidikan maju, dengan sendirinya peradaban juga akan mengalami. 


\section{DAFTAR PUSTAKA}

Adnan Amal, Taufik Islam Tantangan dan Modernitas: Studi Atas Pemikiran Hukum Fazlur Rahman (Bandung Mizan, 19930)

Alparsan, Acigence The Thinker Of Islamic Revival and Revorm: Fzlur Rahman's Life and Thought, 1919-1988, dalam Journal Of Islamic Reserch, Vol.4, 1990

Ahmad, Mumtaz In Memorian Profesor Fzlu Rahman, dalam The American Journal of Islamic Social Science, Vol. 5, No. 1, 1998

Muhadjir, Neong "Pendidikan dalam Persfektif Al-Quran: Tinjau Mikro" dalam pendidikan dalam persfektif Al-Quran Yogyakarta: LPPI UMY, 1999

Muhaimin dkk, Kontroversi pemikiran Fazlur Rahman Cirebon: Pustaka Dinamika, 1999.

Rahman, Fazlur The Qur'anic Solution Of Pakistan's Edication Problems, dalam Sutrisno, Kajian Terhadap Epistimologi dan sistem pendidikan, Cet; 1. Yogyakarta: pustaka pelajar, 2006

---------------,Islam and Moderity Transformation of Intelectual Tradition Chicago and London: The University of Chicago Press, 1984

, An Autobiograhical Note dalam Journal Of Islamic Research, Vol.

4, 1990

, Islami, Cet; 1. Jakarta: Bulan Bintang, 1987 
